\title{
PENINGKATAN HASIL BELAJAR MENULIS TEKS NARRATIVE MENGGUNAKAN MEDIA GAMBAR BERSERI DI SMPN 1 KARANGAN
}

\author{
Ratna Tri Rahayu ${ }^{1)}$ \\ 1) SMP Negeri 1 Karangan \\ elrahma946@gmail.com
}

\begin{abstract}
ABSTRAK: Siswa kelas delapan di SMP akan mendapatkan teks Recount dan Narrative di semester 2. Keduanya memiliki kesamaan dalam menggunakan Simple Past Tense. Jadi penulis tidak menghadapi kesulitan dalam mengajar Kompetensi Dasar 12.2. Tetapi fakta tentang pencapaian siswa berbeda. Hanya ada 57,14 yang dapat mencapai minimum penguasaan siswa. Itulah sebabnya penulis mengadakan penelitian tentang penerapan gambar serial untuk meningkatkan penguasaan siswa dalam menulis teks naratif di Kelas VIII Semester 1 tahun akademik 2014/2015 SMPN 1 Karangan. Penelitian ini bertujuan untuk mengatasi semua masalah. Jadi penelitian yang dilakukan adalah Xlassroom Action Research (CAR) dengan menggunakan 2 siklus 4 tahap. Setelah pembelajaran mengajar menggunakan media, peningkatannya adalah sebagai berikut persentase ketuntasan siswa adalah $57,14 \%$ selama pra-siklus, $67,86 \%$ pada siklus pertama, dan $89,29 / \%$ pada siklus kedua. Rata-rata prestasi siswa telah meningkat dari 64,41 pra siklus, menjadi 74,71 dan 78,25 pada siklus 2. Itu sebabnya kolaborator dan penulis menyimpulkan bahwa penelitian telah meningkatkan prestasi siswa
\end{abstract}

Kata kunci : Teks Naratif, Prestasi, Gambar Berseri

ABSTRACT: The students of eighth grade in SMP will get Recount and Narrative text in semester 2. Both have similarity in using Simple Past Tense. So the writer do not face some diffculty in teaching Basic Competence 12.2. But the fact about the studenys' achivenemt is different. There is only 57,14 who can reach minimum students mastery. That is why the writer hold a research on applying serial picture to improve the students' mastery on writing narrative text in Class VIII A semester 1 academic year 2014/2015 SMPN 1 Karangan. This research is aimed to overcome all problem. So the research conducted is Xlassroom Action Research (CAR) by using 2 cycles 4 stages. After the teaching learning using the media the improvement are as follows the percentage of students's mastey is 57,14\% during precycle, 67,86\% first cycle, and $89.29 / \%$ in second cycle. The avarege of the students' achievements has increased to from 64,41 precycle, become 74,71 and 78,25 in cycle 2. That is why colaborator and the write infer that research has increased the students' achievement

Keywords: Narrative Text, Achievement, Serial Pictures

\section{PENDAHULUAN}

Bahasa Inggris sebagai bahasa Internasional diperkenalkan di SMP dengan mengembangkan empat ketrampilan bahasa Inggris, yaitu mendengarkan (listening), berbicara (speaking), membaca (reading), dan menulis (writing). Adapun jenis teks yang diperkenalkan kepada siswa adalah transaksional/interpersonal, teks fungsional pendek 
dan teks monolog dalam bentuk lisan dan tulis. Empat ketrampilan ini dalam pelaksanaan kegiatan pembelajaran disajikan dalam bentuk Kompetensi yang berbedaJenis teks monolog yang diperkenalkan untuk tingkat SMP adalah: teks Procedure, Descriptive, Recount, Narrative dan Report. Pada siswa kelas VIII semester 2 teks yang diberikan adalah teks Recount dan Narrative. Dua jenis teks ini mempunyai kesamaan yatu menggunakan kalimat-kalimat Simple Past Tense (bentuk lampau). Karena yang disampaikan adalah peristiwa yang sudah berlangsung. Yang membedakan terutama pada susunan teks. Pada teks Recount yang disajikan adalah rangkaian peristiwa (series of events) yang harus disampaikan secara urut sedangkan teks Narrative ada permasalahan (complication) dan penyelesaian (resolution). Pembelajaran teks Narrative pada kelas VIII A semester 2 Tahun Pelajaran 2014/2015 di SMPN 1 Karangan Trenggalek terutama dalam listening dan reading walaupun agak tersendat tetapi bisa berlangsung lancar. Hal ini dibuktikan dengan nilai rata-rata hasil belajar siswa yang baik. Peneliti berharap bahwa hasil belajar siswa juga akan baik pada KD 12.2 yaitu menulis teks Narrative. Apalagi mereka sudah punya bekal awal pengalaman menulis dalam kegiatan sebelumnya yaitu menulis teks Recount sederhana tentang kehidupan mereka sehari-hari. Pada saat kegiatan pembelajaran KD 12.2 menulis teks narrative pendek sederhana, peneliti tidak menemukan kesulitan dalam mendiskusikan kembali tentang struktur teks, unsur-unsur kebahasaan, tujuan komunikatif, dan yang khusus dari teks ini adalah nilai-nilai moral (moral value). Latihan-latihan dalam buku Pendamping Siswa juga bisa mereka kerjakan. Sebagai tahap akhir dari kegiatan pembelajaran adalah uji kompetensi menulis teks Narrative tentang dongeng yang sudah mereka kenal.

Hasil uji kompetensi siswa kelas VIII A SMP Negeri 1 Karangansemester 2 Tahun Pelajaran 2014/2015 kurang memuaskan. Hanya sekitar 57,14 \% siswa yang bisa mencapai nilai KKM menulis. Begitu juga raihan rata-rata kelas yang juga cukup renadah, hanya 64,43 . Ketidaktuntasaan pada KD 12.2 menulis teks narrative pendek sederhana selalu terjadi dari tahun ke tahun. Kesalahan yang dibuat juga tidak lebih sama yaitu terutama dalam pemilihan kosa kata (diction), kurang menguasai susunan kalimat (grammar), dan keruntutan kalimat dalam penulisan (coherence).

Agar permasalahan di kelas VIII A segera dapat diatasi maka peneliti melakukan penelitian dengan judul Peningkatan Hasil Belajar Menulis Teks Narrative Menggunakan Media Gambar Berseri Siswa Kelas VIII A semester 2 Tahun Pelajaran 2014/2015 di SMPN 1 Karangan. Adapun tujuan dalam penelitian ini adalah memberikan deskripsi yang nyata tentang peningkatan hasil belajar menulis teks narrative menggunakan media gambar berseri siswa kelas VIII A semester 2 Tahun Pelajaran 2014/2015 di SMPN 1 Karangan. Dengan adanya penelitian tindakan kelas ini memberikan manfaat yang besar 1) Bagi siswa dapat menciptakan situasi yang menyenangkan dala kegiatan pembelajaran Bahasa Inggris dan dapat meningkatan semangat belajar siswa, sehingga akan meningkatkan prestasi belajar siswa, 2) Bagi Peneliti yaitu dapat meningkatkan kualitas pembelajaran di kelas VIII A, sehingga dapat dikembangkan juga di kelas lain dan dapat digunakan sebagai sarana pengembangan diri secara berkelanjutan, 3) Bagi Sekolah, 
penelitian ini dapat meningkatkan kualitas sekolah melalui peningkatan prestasi belajar siswa dan kinerja guru.

\section{KAJIAN TEORITIS}

Hasil belajar merupakan kemampuan yang diperoleh individu setelah proses belajar berlangsung, yang dapat memberikan perubahan tingkah laku baik pengetahuan, pemahaman, sikap dan keterampilan siswa sehingga menjadi lebih baik dari sebelumnya. Nana Sudjana (2005: 5) menyatakan bahwa hasil belajar siswa pada hakikatnya adalah perubahan tingkah laku dan sebagai umpan balik dalam upaya memperbaiki proses belajar mengajar. Tingkah laku sebagai hasil belajar dalam pengertian luas mencakup bidang kognitif, afektif dan psikomotorik. Suratinah Tirtonegoro (2001:43) mengemukakan hasil belajar adalah penilaian hasil usaha kegiatan belajar yang dinyatakan dalam bentuk simbol, angka, huruf maupun kalimat yang dapat mencrminkan hasil yang sudah dicapai oleh setiap siswa dalam periode tertentu. Syaiful Bahri Djamarah (1996:23) mengungkapkan hasil belajar adalah hasil yang diperoleh berupa kesan-kesan yang mengakibatkan perubahan dalam diri individu sebagai hasil dari aktivitas dalam belajar. Eko Putro Widoyoko (2009:1), mengemukakan bahwa hasil belajar terkait dengan pengukuran, kemudian akan terjadi suatu penilaian dan menuju evaluasi baik menggunakan tes maupun non-tes. Pengukuran, penilaian dan evaluasi bersifat hirarki. Evaluasi didahului dengan penilaian (assessment), sedangkan penilaian didahului dengan pengukuran.

Menulis adalah menuangkan buah pikiran kedalam bentuk tulisan atau menceritakan sesuatu kepada orang lain melalui tulisan. Menulis juga dapat diartikan sebagai ekspresi perasaan yang dituangkan kedalam bentuk tulisan seperti yang dikatakan oleh Burhan Nurgiantoro (1988:273) yang menyatakan bahwa menulis adalah aktivitas aktif produktif ,yaitu yang menghasilkan bahasa. Sementara itu M. Atar Semi (2007:14) dalam bukunya mengungkapkan tentang pengertian menulis adalah sebagai suatu proses kreatif yang memindahkan gagasan kedalam lambang-lambang tulisan.

Menurut Djago Tarigan (2009:5) menulis berarti: mengekspresikan secara tertulis gagasan, ide, pendapat, atau pikiran dan perasaan. Sedangkan St. Y. Slamet (2008:72) mengemukakan bahwa kemampuan menulis adalah kemampuan berbahasa yang bersifat produktif artinya: kemampuan menulis ini merupakan kemampuan yang menghasailkan tulisan. Menurut (Suparno dan Yunus, 2008: 13), menulis dapat didefinisikan sebagai "Suatu kegiatan penyampaian pesan (komunikasi) dengan menggunakan bahasa tulis sebagai alat medianya". Dalam kegiatan pembelajaran ada permasalahan yang dihadapi siswa ketika mereka akan menulis. Oleh karena itu perlu adanya latihan yang cukup untuk mencapai ketrampilan menulis yang baik. Sebagaimana yang disampaikan Solehan dkk. (2008; 94) bahwa kemamapuan menulis bukanlah kemampuan yang diperoleh secara otomatis, melainkan diperoleh melalui tindak pembelajaran. Kesimpulannya, kemampuan menulis adalah kemampuan yang bersifat aktif dan produktif didalam menghasilkan tulisan yang diperoleh melalui proses pembelajaran dan latihan secara terus menerus.

Menurut Jeremy Harmer (2004.11) ada 3 strategi yang harus digunakan oleh guru ada agar pembelajaran menulis dapat menarik siswa, yaitu: 
a. Mendorong siswa untuk memikirkan apa yang akan mereka tulis dengan merencanakan isi tulisan dan rangkaian cerita. Selain itu mereka juga harus tahu tujuan dari tulisan mereka

b. Menyuruh siswa bekerja sama dalam menulis. Pekerjaan suatu kelompok ang menulis dalam 1 lembar kertas akan memancing respon atau ide dari anggota yang lain baik dalam hal kebahasaan maupun isi teks. Memunculkan saran dan pendapat untuk keberhasilan penyelesaian tulisan mereka.

c. Agar dapat mengoreksi tulisan siswa dengan benar akan memerlukan waktu dan tenaga. Maka guru dapat membaca atau meneliti draft mereka terlebih dahulu

Untuk mengetahui kemampuan menulis siswa maka perlu adanya suatu penilaian yang bisa menampilkan informasi yang pasti tentang kemampuan siswa. Penilaian ketrampilan menulis adalah aspek terpenting dalam proses belajar mengajar ketrampilan menulis bahasa Inggris. Hasil penilaian menunjukkan kepada kita apa yang mereka (siswa) tahu dan apa yang mereka (siswa) dapat lakukan. bahwa siswa harus aktif selama pembelajaran berlangsung, baik secara individu maupun kelompok.

Mukarto dan kawan-kawan dalam buku English on Sky 2 (2007:123) menyebtkan bahwa teks narrative adalah teks yang bertujuan untuk menghibur pembaca atau pendengar. Di dalam teks narrative ini selain menghibur juga memberi pelajaran tentang moral atau diistilahkan dengan moral value. Selanjutnya Mukarto juga menjelaskan tentang susunan atau struktur (generic structure ) teks narrative adalah: 1) Orientation atau pengenalan berisi tentang pengenalan tokoh dalam cerita serta waktu dan tempat kejadiannya. 2) Complication berisi tentang gambaran munculnya krisis atau masalah yang dialami oleh tokoh pada cerita tersebut yang harus dipecahkan dan 3) Resolution berisi tentang bagaimana tokoh dari cerita tersebut memecahkan masalah yang ada pada bagian complication.

Biasanya didalam teks-teks bahasa Inggris terdapat berapa ciri-ciri tata bahasa yang khusus pada teks. Dalam buku Materi ToT KTSP Bagi Pengurus MGMP Bahasa Inggris SMP/SMA/SMK Propinsi Jawa Timur (2007:100) disebutkan tentang ciri-ciri kebahasaan teks narrative, antara laian:

1) menggunakan nouns tertentu sebagai kata ganti orang, hewan dan benda tertentu dalam cerita, misalnya: stepsister, house work

2) menggunakan adjectives yang membentuk noun phrase, misalnya: long black hair, two red apples

3) menggunakan time connectives dan conjunctions then, before, after, soon dan sebagainya untuk menjelaskan kejadian-kejadian, misalnya

4) menggunakan adverbs dan adverbial phrase untuk menunjukkan lokasi kejadian atau peristiwa, misalnya: here, in the mountain, in the remote place, under shady tree

5) mengunakan action verb dalam bentuk past tense, misalnya: ate, ran away, tried to save

Mengenai istilah suatu media yang digunakan untuk mendukung proses belajar mengajar, ada beberapa ahli yang menyebutnya dengan istilah media pembelajaran, ada juga yang menyebut dengan media pendidikan. Pada dasarnya semua istilah itu 
mengandung konsep/pengertian yang sama. Menurut Djamarah dan Zain (2002: 136), kata media berasal dari bahasa Latin dan merupakan bentuk jamak dari kata medium, yang secara harfiah berarti perantara atau pengantar dengan demikian, media merupakan wahana penyalur informasi belajar atau penyalur pesan. Bila media adalah sumber belajar, maka secara luas media dapat diartikan dengan manusia, benda, ataupun peristiwa yang memungkinkan anak didik memperoleh pengetahuan dan keterampilan.

Secara umum media dapat diklasifikasikan menjadi 3 jenis media. Sebagaimana yang sudah diungkapkan Djamarah dan Zain (dalam Hasnindah 2011:8), yaitu a. media auditif (mengandalkan kemampuan suara) b. Media visual (mempunyai unsur gambar) c,. media audio visual (mempunyai unsur suara dan gambar). Media gambar berseri bila dilihat dari jenisnya termasuk media visual yakni media yang mengandung unsur gambar saja. Sapari (dalam Hasnindah 2011: 8) mengemukakan bahwa gambar berseri adalah serangkaian gambar yang terdiri dari 2 atau 6 gambar yang menceritakan suatu kesatuan cerita yang dapat dapat dijadikan alur pemikiran siswa dalam mengarang. Selanjutnya Dina Indriana (2011:65) menjelaskan bahwa media gambar mampu memberikan detail dalam bentuk gambar apa adanya, sehingga anak didik mampu untuk mengingatnya, Pendapat di atas menegaskan bahwa gambar berseri adalah media yang berisi serangakain gambar yang setiap gambar terkait satu dengan lainnya yang membentuk suatu rangkaian cerita berdasarkan urutan gambar. Masing-masig gambar dalam media gambar berseri mengandung makna tertentu sehingga penyusunan gambar harus benar-benar menggambarkan urutan kejadian. Keberadaan dan fungsi media gambar berseri ini memiliki fungsi dalam manfaat dalam mendukung kegiatan pembelajaran karena dia akan menjaga siswa dalam mengarang agar sesuai dengan alurnya.

Adapun gambar berseri yang digunakan dalam pembelajaran Bahasa Inggris KD 12.2 kelas VIII semester 2 khususnya menulis teks narrative pendek ada 2 jenis. Yang pertama adalah gambar berseri tentang fabel yaitu cerita tentang binatang sebagai tokonhnya yang bertindak sebagai manusia, seperti berikut ini
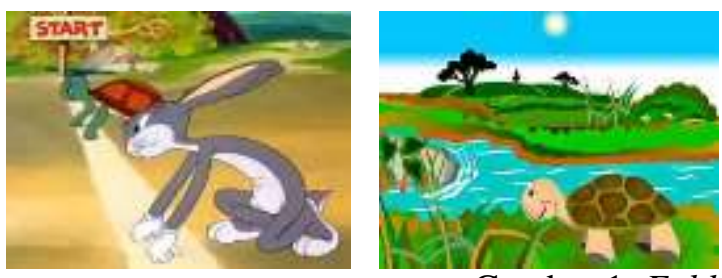

Gambar 1. Fable the rabbit and slow turtle

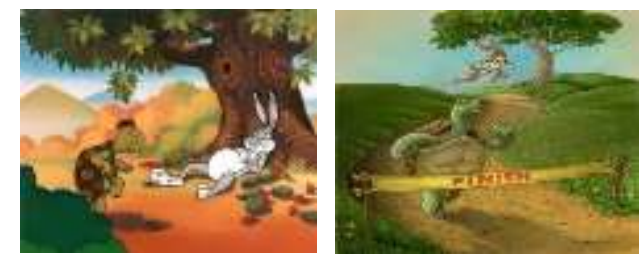

Sedangkan yang dalam siklus kedua adalah gambar berseri tentang fairy tale yaitu cerita yang berisi tentang fantastik dan penuk dengan keajaiban, dengan jumlah yang lebih banyak, yaitu 6 gambar. Seperti pada gambar berikut :

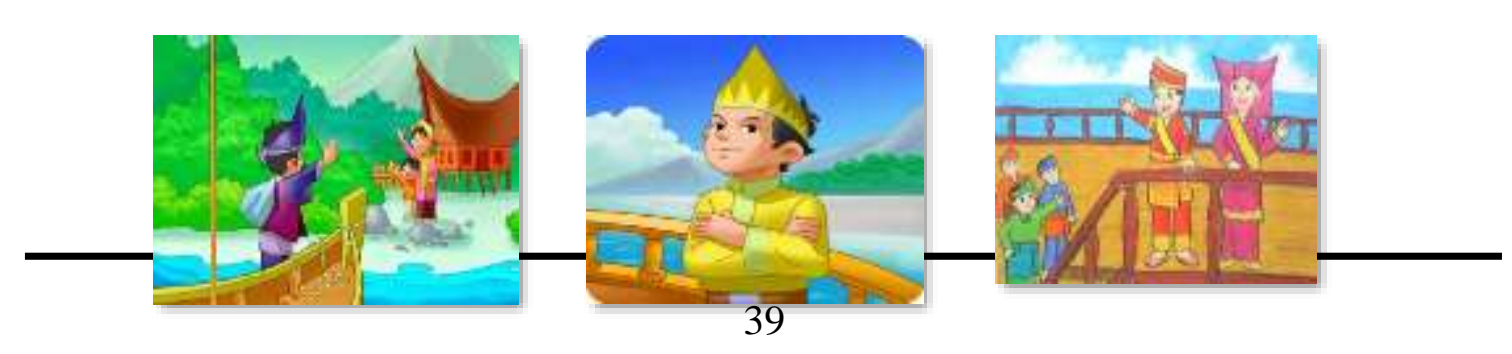



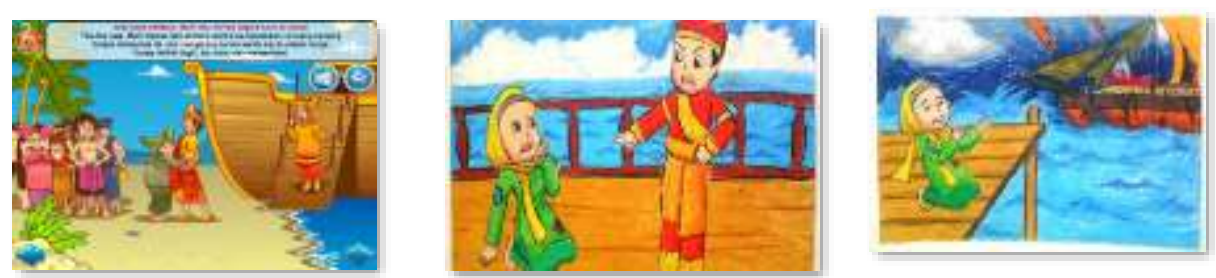

Gambar 2. Contoh Gambar Berseri tentang Malin Kundang

Media gambar berseri ini digunakan pada pertemuan kedua, dengan tujuan untuk mempermudah siswa dalam menentukan kata kerja yang akan mereka gunakan dalam tulisan mereka. Oleh karena itu gambar disajikan sudah dalam 1 rangkaian utuh. Adapun langkah-langjah penggunaan media gambar berseri adalah sebagai berikut:

1) Siswa diminta membentuk kelompok yang terdiri dari 4 anak

2) Guru membagikan lembar kerja berisi tes narrative sederhana

3) Bersama kelompoknya siswa menuliskan struktur pada teks narrative

4) Guru membagikan media gambar berseri tentang The Rabbit and Slow Turtle

5) Guru dan siswa mendiskusikan action verb dari gambar berseri

6) Guru membagikan lembar kelompok

7) Siswa menuliskan action di bawah gambar se

8) Bersama kelompoknya siswa membuat teks Narrative beradasarkan media gambar berseri yang diterima

9) Salah satu anggota mempresentasikan pekerjaannya.

10) Guru memberi masukan atas pekerjaan siswa

11) Secara individu siswa mengerjakan uji kompetensi menulis teks narrative tentang binatang (fable)

\section{METODE PENELITIAN}

Penelitian yang dilakukan pada kelas VIII A semester 2 tahun pelajaran 2014/2015 adalah merupakan Penelitian Tindakan Kelas (PTK) karena mempunyai tujuan untuk menyelesaikan permasalahan yang ada dikelas ini. Untuk itu peneliti mengacu pada penelitian model Kemmis dan Taggart sebagaimana tercantum dalam Taggart (dalam Arikunto, 2002: 83) yang mengemukakan bahwa pelaksanaan PTK dilakukan dalam bentuk siklus. Tiap siklus dilaksanakan dalam empat tahap, yaitu: 1) Perencanaan (planning, 2) Pelaksanaan atau tindakan (Acting), 3) Pengamatan atau observasi (observing), 4) Refleksi (reflecting)

\section{Tahap perencanaan}

Pada tahap ini, peneliti dibantu kolaborator menyiapkan segala perangkat pembelajaran yang akan dipergunakan pada saat melakukan penelitian. Adapun yang dipersiapkan adalah: 
a. Silabus pembelajaran Bahasa Inggris KD 12.2 menulis teks narrative sederhana dengan menggunakan gambar berseri

b. Rencana Pelaksanaan Pembelajaran (RPP) KD 12.2 menulis teks narrative sederhana dengan menggunakan gambar berseri

c. Lembar Kerja Siswa

d. Media pembelajaran berupa gambar berseri

e. Format penilaian menulis

f. Dan pendukung pelaksanaan penelitian yang lain.

2. Tahap tindakan

Setelah menyiapkan semua komponen penelitian, maka peneliti melaksanakan kegiatan pembelajaran sesuai dengan rencana yang sudah dibuat, yakni hari Selasa tanggal 10 Pebruari 2015 untuk pertemuan 1 pada jam pertama dan kedua kemudian pertemuan kedua dilaksanakan pada hari Kamis tanggal 12 Pebruari 2015 pada jam ketiga dan keempat..

Pada pertemuan 1 media gambar berseri belum digunakan karena masih memberikan latihan-latihan yang berhungan dengan kebahasaan. Setelah melakukan kegiatan awal lalu diteruskan dengan kegiatan inti. Adapun rincian kegiatan inti pada pertemuan 1 adalah sebagai berikut :

a. Guru mereview tentang generic structure teks Narrative

b. Guru membagikan lembar kerja siswa kepada setiap siswa

c. Siswa mengubah kalimat-kalimat Present Tense menjadi kalimat-kalimat Past Tense

d. Guru dan siswa mendiskusikan jawaban

e. Siswa bersama temannnya sebangku menyusun kata-kata yang acak menjadi kalimat yang benar

f. Guru dan siswa mendiskusikan jawaban

g. Bersama teman satu bangku siswa menyusun kalimat yang acak menjadi satu paragraf narrative yang benar

h. Guru dan siswa mendiskusikan jawabannya

Pada pertemuan kedua, kegiatan utama adalah penggunaan media untuk kerja kelompok dan uji kompetensi menulis teks narrative. Langkah-langkah penggunaan media gambar berseri dapat dilihat dari rancangan kegiatan berikut ini:

a. Siswa diminta membentuk kelompok yang terdiri dari 4 anak

b. Guru membagikan lembar kerja berisi tes narrative sederhana

c. Bersama kelompoknya siswa menuliskan struktur pada teks narrative

d. Guru membagikan media gambar berseri tentang The Rabbit and Slow Turtle

e. Guru dan siswa mendiskusikan action verb dari gambar berseri

f. Guru membagikan lembar kelompok

g. Siswa menuliskan action di bawah gambar se

h. Bersama kelompoknya siswa membuat teks Narrative beradasarkan media gambar berseri yang diterima

i. Salah satu anggota mempresentasikan pekerjaannya.

j. Guru memberi masukan atas pekerjaan siswa

$\mathrm{k}$. Secara individu siswa mengerjakan uji kompetensi menulis teks narrative tentang binatang (fable)

Kemudian guru menutup kegiatan pembelajaran dengan bersama-sama siswa membuat rangkuman/simpulan pelajaran, melakukan penilaian dan/atau refleksi 
terhadap kegiatan yang sudah dilaksanakan secara konsisten dan terprogram, memberikan umpan balik terhadap proses dan hasil pembelajaran dan menyampaikan rencana pembelajaran pada pertemuan berikutnya.

3. Tahap observasi

Pada tahap ini, peneliti mengumpulkan hasil/data serta mengamatinya, ada dampak atau tidak terhadap siswa. Hal itu dapat diketahui melalui hasil belajar siswa dan pengamatan langsung terhadap perilaku siswa. Disini peneliti dibantu oleh seorang kolaborator.

4. Tahap refleksi

Pada dasarnya tahap refleksi merupakan kegiatan analisis terhadap semua informasi yang diperoleh saat kegiatan pelaksanaan tindakan. Dalam kegiatan ini, peneliti mengkaji, melihat dan mempertimbangkan hasil-hasil atau dampak dari tindakan. Melalui refleksi dapat ditarik kesimpulan yaitu perubahan sebagai akibat dari tindakan yang diperlukan.

Penelitian tindakan kelas ini dilaksanakan di kelas VIII A SMP Negeri 1 Karangan pada semester 2 tahun pelajaran 2014/2015 adalah kelas VIII A dengan jumlah siswa 28. Dalan kegiatan ini peneliti menggunakan 1 jenis instrumen penelitian, yaitu tes dalam bentuk uji kompetensi menulis teks pendek berbentuk Narrative. Penggunaan instrument dalam penelitian ini adalah untuk mengukur kemampuan siswa dalam memahami unsur-unsur menulis teks Narrative. Unsur-unsur tersebut adalah diction/vocabulary (pemilihan kata, grammar (susunan kalimat), dan coherence (kalimat yang berkesinambungan). Adapun pengumpulan data dalam penelitian ini dilaksanakan diakhir kegiatan pembelajaran pada pertemuan 2 pada tiap siklus. Setelah data terkumpul maka peneliti dan kolaborator melakukan analisis data sebagaimana berikut:

1. Nilai menulis teks Narrative.

Nilai menulis teks Narrative diolah dengan cara memberikan skor dari masingmasing unsur pada rubrik penilaian menulis teks Narrative. Kemudian menjumlah semua skor yang diperoleh siswa dari unsur-unsur tersebut lalu membagi jumlah nilai itu dengan total skor maksimal kemudian dikalikan 100.

Adapun rumus untuk menentukan hasil akhir adalah sebagai berikut:

$$
\mathrm{N}=\frac{\sum N S}{\sum N \max } \times 100
$$

Keterangan:

$\mathrm{N}$ : nilai akhir siswa

$\sum N S$ : jumlah semua nilai yang diperoleh siswa dari masing-masing unsur.

$\sum N$ max: jumlah nilai maksimal dari semua unsur.

\section{Nilai rata-rata}

Nilai rata-rata menulis teks Narrative ditentukan dengan cara menjumlah semua nilai perolehan seluruh siswa kemudian membaginya dengan jumlah siswa. Adapun rumus untuk menentukan nilai rata-rata adalah sebagai berikut:

$$
\mathrm{RN}=\frac{\sum N}{\sum S}
$$

Keterangan: 
$\mathrm{RN}$ : Nilai rata-rata

$\sum N$ : Jumlah nilai seluruh siswa

$\sum S$ : Jumlah seluruh siswa

\section{Persentasi ketuntasan}

Persentasi ketuntasan dianalisa dengan cara membagi jumlah siswa yang telah tuntas dengan jumlah seluruh siswa kemudian dikalikan 100 persen, sebagaimana rumus berikut ini

$$
\mathrm{PK}=\frac{\sum K}{\sum S} \times 100 \%
$$

Keterangan:

PK: Presentasi ketuntasan

$\sum K$ : Jumlah siswa yang tuntas

$\sum S$ : Jumlah seluruh siswa

$100 \%$ : Standar presentasi ideal

Data yang diperoleh dari tes dipaparkan secara deskriptif untuk menggambarkan kondisi siswa berkenaan dengan kegiatan menulis teks Narrative. Pencapaian target nilai rata-rata kelas mata pelajaran Bahasa Inggris yaitu 75. Apabila nilai rata-rata kelas siswa lebih kecil dari 75, maka kegiatan pembelajaran menulis teks Narrative belum berhasil. Sebaliknya, apabila nilai rata-rata kelas siswa lebih besar atau sama dengan 75 , maka kegiatan pembelajaran menulis teks Narrative dinyatakan berhasil. Sedangkan indikator ketuntasan klasikal adalah $80 \%$. Hal ini selaras dengan yang termuat dalam buku 1 kurikulum bahwa bahwa kegiatan pembelajaran akan dikatakan tuntas secara klasikan apabila persentasi keruntasan sama atau lebih dari $85 \%$ Setelah semua data yang diperoleh dianalisis maka hal yang terakhir dilakukan adalah memadukan perolehan data secara keseluruhan untuk menuju pada kesimpulan melalui grafik perbandingan

\section{HASIL DAN PEMBAHASAN}

\section{Siklus 1}

Dari hasil analisis dapat diketahui pada tindakan siklus 1, ada peningkatan pada hasil belajar siswa dalam menulis text narrative pendek dengan tema fabel. Secara lengkap hasilbelajar siswa dapat diketahui dari tabel 1 berikut ini:

Tabel 1. Hasil Uji Kompetensi menulis teks narrative siklus 1

\begin{tabular}{|c|c|c|c|c|c|c|c|}
\hline No & Nilai $(\mathbf{N})$ & Frek. (F) & $\%$ & $\mathbf{F} \mathbf{X}$ & Keterangan & $\mathbf{J m l}$ & $\%$ \\
\hline 1 & 100 & 0 & 0 & 0 & Tuntas & \multirow{5}{*}{19} & \multirow{5}{*}{67,86} \\
\hline 2 & 93 & 3 & 10,71 & 279 & Tuntas & & \\
\hline 3 & 87 & 4 & 14,29 & 348 & Tuntas & & \\
\hline 4 & 80 & 5 & 17,86 & 400 & Tuntas & & \\
\hline 5 & 73 & 7 & 25,00 & 511 & Tuntas & & \\
\hline
\end{tabular}




\begin{tabular}{|c|c|c|c|c|c|c|c|}
\hline 6 & 67 & 4 & 14,29 & 268 & $\begin{array}{l}\text { Belum } \\
\text { Tuntas }\end{array}$ & \multirow{4}{*}{9} & \multirow{4}{*}{32,14} \\
\hline 7 & 60 & 3 & 10,71 & 180 & $\begin{array}{l}\text { Belum } \\
\text { Tuntas }\end{array}$ & & \\
\hline 8 & 53 & 2 & 7,14 & 106 & $\begin{array}{l}\text { Belum } \\
\text { Tuntas }\end{array}$ & & \\
\hline 9 & 47 & 0 & 0,00 & 0 & $\begin{array}{l}\text { Belum } \\
\text { Tuntas }\end{array}$ & & \\
\hline Jumlah & & 28 & 100,00 & 2092 & 0 & 28 & 100,00 \\
\hline & Rata- & & 74,71 & & & & \\
\hline
\end{tabular}

Tabel di atas dapat diketahui perkembangan hasil belajar siswa kelas VIII A SMP negeri 1 Karangan setelah melakukan kegiatan pembelajaran menulis teks narrative menggunakan media gambar berseri yang mengalami peningkatan bila dibandingkan dengan kondisi pada saat pra siklus. Nilai rata-rata kelas mengalami peningkatan dari 64,43 pada saat pra siklus, menjadi 74,71 pada siklus 1. Demikian juga dengan persentase ketuntasan klasikal. Siswa yang berhasil menuntaskan KD ini meningkat menjadi 19 siswa dari 28 atau $67,86 \%$ padahal pada saat pra siklus ketuntasan klasikal hanya $57,14 \%$ atau 16 siswa yang tuntas. Walaupun sudah ada peningkatan setelah siklus 1, tetapi belum memenuhi target peneliti bahwa nilai rata-rata kelas sama atau diatas 75 . Begitu juga ketuntasan klasikal yang diharapkan adalah sama atau lebih $80 \%$. Untuk itu kolaborator dan peneliti memutuskan bahwa penelitian tindakan kelas belum berhasil dan dilanjutkan pada siklus 2

\section{Siklus 2}

Hasil uji kompetensi menulis teks narrative pada siswa kelas VIII A segera dianalisis untuk mengetahui perkembangan hasil belajar mereka. Secara lengkap peningkatan hasil belajar siswa pada siklus 2 dapat diketahui dari tabel 4.2 berikut ini:

Tabel 2. Hasil Uji Kompetensi menulis teks narrative siklus 2

\begin{tabular}{|c|c|c|c|c|c|c|c|}
\hline No & $\begin{array}{c}\text { Nilai } \\
(\mathrm{N})\end{array}$ & $\begin{array}{c}\text { Frek. } \\
\text { (F) }\end{array}$ & $\%$ & $\mathbf{F} \mathbf{X} \mathbf{N}$ & Keterangan & Jml & $\%$ \\
\hline 1 & 100 & 2 & 7,14286 & 200 & Tuntas & \multirow{5}{*}{25} & \multirow{5}{*}{89,29} \\
\hline 2 & 93 & 4 & 14,29 & 372 & Tuntas & & \\
\hline 3 & 87 & 3 & 10,71 & 261 & Tuntas & & \\
\hline 4 & 80 & 8 & 28,57 & 640 & Tuntas & & \\
\hline 5 & 73 & 10 & 35,71 & 730 & Tuntas & & \\
\hline 6 & 67 & 2 & 7,14 & 134 & Belum Tuntas & \multirow{4}{*}{3} & \multirow{4}{*}{10,71} \\
\hline 7 & 60 & 1 & 3,57 & 60 & Belum Tuntas & & \\
\hline 8 & 53 & 0 & 0,00 & 0 & Belum Tuntas & & \\
\hline 9 & 47 & 0 & 0,00 & 0 & Belum Tuntas & & \\
\hline Jumla & & 28 & 100,00 & 2197 & $\mathbf{0}$ & 28 & 100,00 \\
\hline
\end{tabular}


Berdasarkan tabel diatas dapat disimpulkan bahwa telah terjadi peningkatan hasil belajar menulis teks narrative pendek sederhana setelah penggunaan gambar berseri pada kelas VIII A SMP Negeri 1 Karangan semester 2 tahun pelajaran 2014/2015. Peningkatan ini terjasi pada nilai rata-rata kelas pada saat siklus 1 adalah 74,71, pada saat siklus 2 meningkat menjadi 78,46 . Nilai rata-rata ini sudah diatas target nilai rata-rata yang diharapkan yaitu 75,00. Siswa yang tidak tuntas berkurang menjadi 3 siswa atau tinggal $10,71 \%$. Dengan demikian siswa yang bisa mencapai ketuntasan meningkat menjadi 25 siswa dari 20 kalau dipersentase menjadi 89,29\%. Persentase ini sudah melampaui target yang ditentukan yaitu $80 \%$..Melihat hasil penelitian yang demikian maka disepakati oleh peneliti dan kolaborator bahwa pembelajaran dengan media gambar berseri dapat meningkatkan hasil belajar menulis teks narrative siswa kelas VIII A semester 2 tahun pelajaran 2014/2015 di SMP Negeri 1 Karangan

Hasil akhir dari tindakan kelas ini adalah meningkatnya hasil belajar siswa pada KD 12.2 menulis teks narrative di kelas VIII A semester 2 tahun pelajaran 2014/2015 SMP Negeri 1 Karangan. Peningkatan hasil belajar siswa mulai pra siklus, siklus 1 dan siklus 2 dapat dilihat pada tabel 4.3 berikut ini.

Tabel 3. Peningkatan Hasil belajar Siswa Prasiklus, Siklus 1 dan siklus 2

\begin{tabular}{|l|l|c|c|c|c|c|}
\hline \multirow{2}{*}{$\mathbf{N}$} & \multirow{2}{*}{ Siklus } & \multicolumn{4}{|c|}{ Rentang Nilai } & \multirow{2}{*}{ Rata-Rata } \\
\cline { 3 - 6 } & & \multicolumn{2}{|c|}{ Ketidaktuntasan } & \multicolumn{2}{c|}{ Ketuntasan } & \\
\hline 1. & Pra Siklus & $42,86 \%$ & 12 & $57,14 \%$ & 16 & 64,41 \\
\hline 2. & Siklus 1 & $32,14 \%$ & 9 & $67,86 \%$ & 19 & 74,71 \\
\hline 3. & Siklus 2 & $10,71 \%$ & 3 & $89.29 / \%$ & 25 & 78,86 \\
\hline
\end{tabular}

Apabila dikonversikan pada grafik perbandingan dapat tergambar sebagai berikut: 


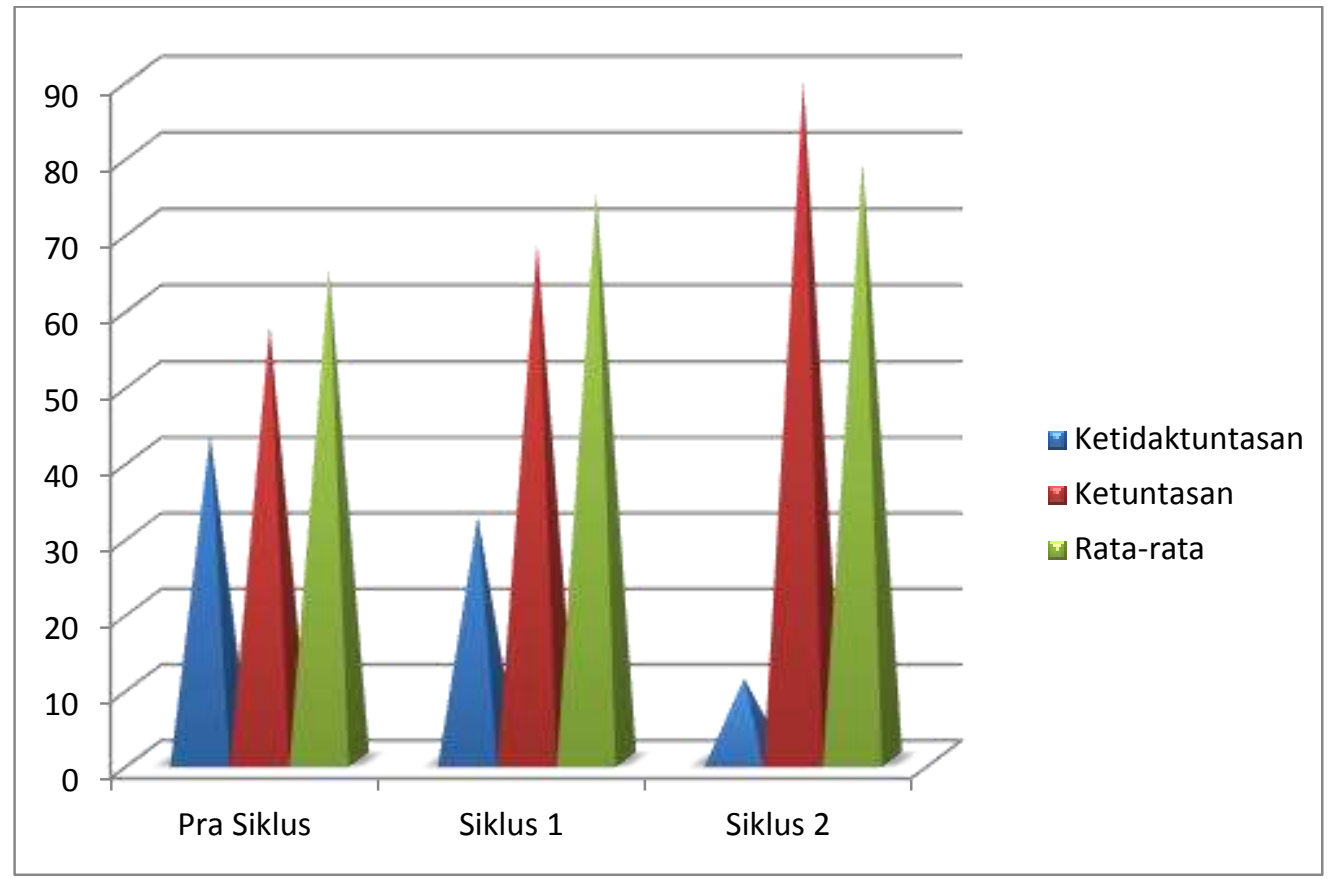

Grafik 1. Peningkatan Hasil belajar Siswa Prasiklus, Siklus 1 dan siklus 2

Dari grafik diatas terlihat perkembangan nyata dari kondisi pra siklus, siklus 1 hingga siklus 2, rentang persentase siswa yang belum tuntas (warna biru) pada saat pra siklus sebesar $42,86 \%$ berkurang menjadi $32,14 \%$ pada siklus 1 dan berkurang lagi menjadi $10,71 \%$ pada saat siklus 2. Sedangkan persentase siswa yang tuntas (warna merah tua) pada saat pra siklus sebesar $57,14 \%$, pada saat siklus 1 meningkat menjadi $67,86 \%$, dan meningkat lagi menjadi $89.29 / \%$ pada saat siklus 2. Demikian pula dengan nilai rata-rata kelas VIII A (warna hijau) pada saat pra siklus adalah 64,41 , pada saat siklus 1 meningkat menjadi 74,71dan meningkat lagi menjadi 78,25 pada siklus 2 . maka dari itu peneliti dan kolaborator menyepakati bahwa hasil ini sudah memenuhi target yang ditentukan, artinya penelitian tindakan melalui media gambar berseri dalam menulis teks narrative pada siswa kelas VIII A semester 2 tahun pelajaran 2014/2015

\section{KESIMPULAN DAN SARAN}

Kesimpulan dari penelitian ini adalah terjadi peningkatan dari kondisi pra siklus, siklus 1 hingga siklus 2, rentang persentase siswa yang belum tuntas pada saat pra siklus sebesar $42,86 \%$ berkurang menjadi $32,14 \%$ pada siklus 1 dan berkurang lagi menjadi $10,71 \%$ pada saat siklus 2 . Sedangkan persentase siswa yang tuntas pada saat pra siklus sebesar $57,14 \%$, pada saat siklus 1 meningkat menjadi $67,86 \%$, dan meningkat lagi menjadi $89.29 / \%$ pada saat siklus 2. Demikian pula dengan nilai rata-rata kelas VIII A pada saat pra siklus adalah 64,41, pada saat siklus 1 meningkat menjadi 74,71dan meningkat lagi menjadi 78,25 pada siklus 2 . maka dari itu peneliti dan kolaborator menyepakati bahwa hasil ini sudah memenuhi target yang ditentukan, artinya penelitian tindakan melalui media gambar berseri dalam menulis teks narrative pada siswa kelas VIII A semester 2 tahun pelajaran 2014/2015 
Berdasarkan pengalaman selama melaksanakan Penelitian Tindakan Kelas di SMP Negeri 1 Karangan Kabupaten Trenggalek semester 2 tahun pelajaran 2014/2015 maka dapat diajukan saran-saran sebagai berikut: 1) Guru sebagai pengelola pembelajaran di kelas dituntut kreaktif dalam mecari media pembelajaran yang sesuai dan menarik untuk penyampaian materi, seperti halnya medai gambar berseri yang terbukti efektif dapat menungkatkan hasil belajat menulis teks prosedur pendek, 2) Guru hendaknya berperan sebagai fasilitator dan mampu meminimalkan dominasi dalam proses pembelajaran dan mengoptimalkan aktivitas, kreativitas dan kemampuan siswa, 3) Sekolah sebaiknya selalu memberikan sarana dan prasarana yang baik untuk pengembangan pembelajaran dengan berbagai metode.

\section{DAFTAR PUSTAKA}

Abbas. Hasnindah. 2011: "Meningkatkan Hasil Belajar Bahasa Indonesia Ketrampilan Menulis Materi Membuat Karangan Melalui Media Gambar Seri Pada Muris Siswakelas V SDN Sudirman III . Makassarfip: FIP UNM

Djamarah, Saiful Bahri. 1996. Prestasi Belajar dan Kompetensi Guru. Jakarta: Usaha Nasional

Harmer, Jeremy. 2004, How To Teach Writing. England; Pearson Education Ltd.

Education Ltd, 2004) p. 11 Indriana, Dina. 2011: Ragam Alat Bantu Media Pengajaran. Jogjakarta: Diva Press,

Mukarto, et al. 2004. English on Sky 2. Jakarta. PT Gelora Aksara Pratama

Nana Sudjana. 2005. Dasar-dasar Proses Belajar Mengajar. Bandung: PT.Sinar Baru Algesindo.

Ngalim Purwanto. 2002. Prinsip-prinsip dan Teknik Evaluasi Pengajaran. Bandung: Remaja Rosdakarya.

Nurgiantoro, Burhan. 1988. Penilaian Dalam Pengajaran Bahasa dan Sastra, Yogyakarta : BPFE

Semi, M. Atar. 2007. Dasar - Dasar KetrampilanMenulis, Bandung: Angkasa

Slameto.2010. Belajar dan Faktor-Faktor yang Mempengaruhinya. Jakarta: Rineka Cipta Slamet,

St. Y. 2008. Dasar- Dasar Ketrampilan Berbahasa Indonesia, Surakarta : Universitas Sebelas Maret Press.

Sugihartono, dkk. 2007. Psikologi Pendidikan. Yogyakarta: Uny Press

Suharsimi, Arikunto. 2006. Prosedur Penelitian Suatu Pendekatan Praktik. Jakarta: Rineka Cipta.

Suparno dan Mohamad Yunus. 2008. Ketrampilan Dasar Menulis. Jakarta : Universitas Terbuka

St. Y. Slamet, 2008. Dasar-DasarPembelajaran Bahasa dan Sastra Indonesia di Sekolah Dasar, Surakarta : UNS Press.

Tarigan. Djago H.G. 1986. Teknik Pengajaran Ketrampilan Berbahasa. Bandung : Penerbit Angkasa.

T.W. Solehan dkk. 2008. PendidikanBerbahasa Indonesia di SD. Jakarta: Universitas Terbuka

Tirtonegoro, Suratinah. 2001. Penelitian Hasil Belajar Mengajar. Surabaya: Usaha Nasional. 
Volume 3, Nomor 1, Februari 2019

Widoyoko, Eko Putro S. 2009. Evaluasi Program Pembelajaran. Yogyakarta: Pustaka Pelajar. 